\title{
BUILDING INDONESIAN FOOD SECURITY A REVIEW AND SUGGESTIONS
}

\section{Endah Sri Redjeki}

Agricultural Faculty, University of Muhammadiyah Gresik

endah.sriredjeki@umg.ac.id

\begin{abstract}
Availability, access, utilization, and stability access are the central canal between economic distresses and food security. Food security in pandemic era should sort out with conservation, seed banks, building water reservoir, urban farming, and those programs involved the Penta helix to speed gaining the goals. The Government, private sectors, institutions, local community, and social entrepreneurs have to work all together to succeed in food security.
\end{abstract}

Key words: conservation, food security, pandemic, Penta helix

\section{ABSTRAK}

Ketersediaan, akses, pemanfaatan, dan akses stabilitas adalah kanal pusat antara tekanan ekonomi dan ketahanan pangan. Ketahanan pangan di era pandemi harus memilah-milah dengan konservasi, bank benih, membangun waduk air, pertanian perkotaan, dan program-program yang melibatkan helix Penta untuk mempercepat mendapatkan tujuan. Pemerintah, sektor swasta, lembaga, masyarakat lokal, dan pengusaha sosial harus bekerja sama untuk menyukseskan ketahanan pangan.

Kata kunci: konservasi, ketahanan pangan, pandemi, Penta helix Introduction

\section{INTRODUCTION}

Food security works when all people, at all times, have physical and financial access to ample secure and healthy food that meets their nutritional needs and food favorites for an active and beneficial life. Four principal dimensions of food security can be ordinary: substantial availability of food, economic and physical access to food, sufficient food utilization, and stability of the other three dimensions over time (Food and Agriculture Organization of the United $\mathrm{Na}, 2003$ ). Among the four aspects of food security, availability, access, utilization and stability access are the principal channel between economic shocks and food security and nutrition, mainly through two pillars of accessibility (supply through the market or home-production) and affordability (household income from farm and non-farm activities). Both of which are directly related to agricultural income and non-farm employment (Braun, 2008.).

The Schedule for Sustainable Development Goals (SDGs) puts in advance an improving vision that our world is better if we are to live in a world without famine, food insecurity and malnutrition in any of its forms. More than 820 million people in the 
earth are still famine recently, underscoring the tremendous opportunity of gaining the Zero Hunger target by 2030 . On the other hand, the prevalence of undernourishment in South Asia is still the highest in Asia. Another annoying fact is that about 2 billion people in the world experience moderate or severe food insecurity (United Nation, 2015).

The food system holds an essential role in achieving the UN SDGs, to end hunger through making food security and improving nutrition (SDG2) and to ensure sustainable consumption and production (SDG12). Therefore, Food Insecurity (FI) has to decrease to escalate human health as well as planetary health. These circle activities of monitoring and evaluation displays in Figure 1.

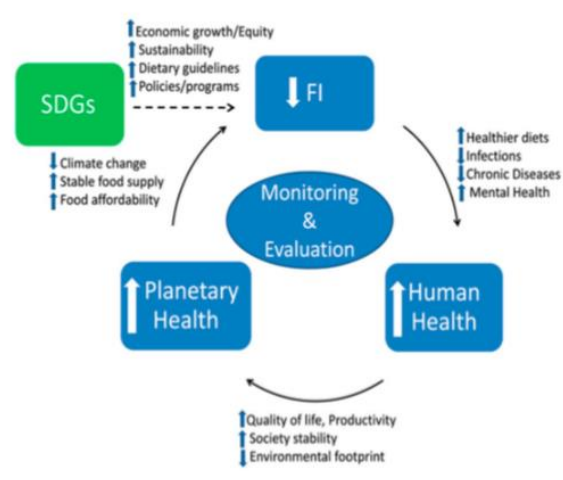

Figure 1 Conceptual framework of Food Insecurity (FI) and the Sustainable Development Goals (SDGs) from human to planetary health (Pérez-Escamilla, 2017).

Food Insecurity (FI) and Vulnerability Information and Mapping Systems (FIVIMS)

Food Insecurity and Vulnerability Information and Mapping Systems (FIVIMS) for instance, identify 15 "information domains" to aid in understanding the causes of inadequate food consumption and nutritional status.
These can be seen in Figure 2 and range from the individual to the household to the national; in turn, these concepts are further underpinned by several contextual factors whose understanding and interplay are the subject of much research (FIVIMS, 2002).

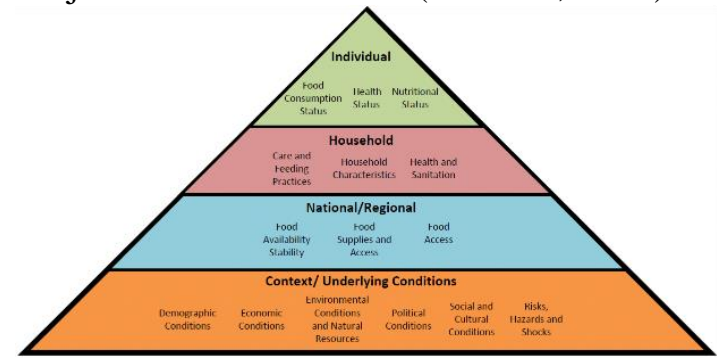

Figure 2. Different levels of food security. Based on ideas from the Committee on the FIVIMS initiative (FIVIMS, 2002) and Food Security (FAO, IFAD, UNICEF, WFP and WHO, 2019).

Furthermore, there are the twin-track approaches to succeed food security in era pandemic Covid19 (Pingali, P., Alinovi, L. \& Sutton,J, 2005). The first action mentions recovery measures for establishing flexible food systems. Food system affected by the structure of the food economy as a whole, as well as its components such as agricultural production, technology, the diversification of food processing, markets and consumption. The second track assesses the options for providing support to vulnerable groups. Vulnerability analysis offers a forward-looking way of understanding food security dynamics, calling for explicit attention to risk and the prospects for managing it. Both tracks intended to be mutually reinforcing, and the positive interaction between them should strengthen the path to recovery. For example, managing risks goes beyond assisting those affected by a particular shock in addressing their immediate food needs. A range of options is available for addressing longerterm food security through sustainable agricultural and rural development aimed at preventing or mitigating risk. 


\section{Food System in Pandemic Era}

There are four significant problems that the food industry and supply chain should be aware in the new era. Firstly, consumers are looking to protect themselves including their immune system by adopting healthier diets, the availability of bioactive ingredients of food and healthy foods may become critical, as the demand for these products may increase. Secondly, food safety is a significant issue to stop the spreading of the virus within stake holders. Thirdly, food security problem has emerged due to the lockdown of a billion people inside their houses. The food systems in the period of pandemics is additional issue that the sector should address to restrict relevant crises in the future.

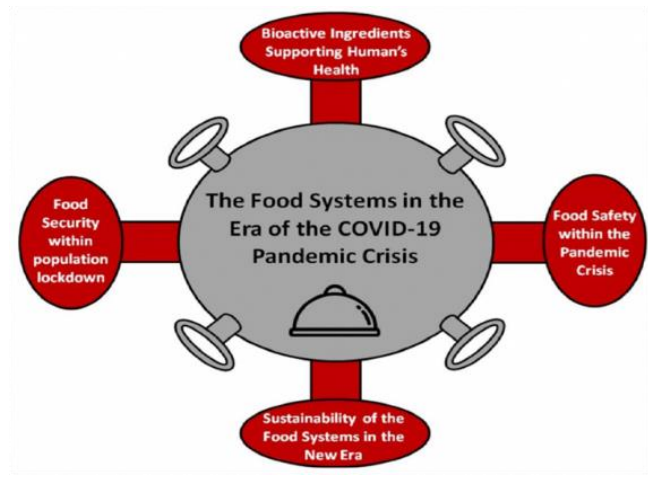

Figure 3. The food systems in the era of the coronavirus disease (COVID-19) pandemic crisis (Galanakis., 2020).

\section{Indonesia in Pandemic Covid19 Era}

Indonesia, with nearly 267 million population, continues to experience natural disasters with increasing intensity every year. The sudden increase in rainfall intensity as a result of climate change, and some districts in Indonesia hit by extreme drought in 2019. Glasshouse gas emissions continue to rise, threatening the Indonesian economy and people's way of life (WRI.Indonesia.org, 2019) and the current disaster is pandemic Covid19. Even though the pandemic destroyed many countries worldwide, still there is a lesson to be learnt. The Covid19 pandemic wisdom is "Hidden Blessings", where pollution reduced (CO2 and $\mathrm{NO} 2$ emissions), and nature claims itself again. This positive impact on the environment may be temporary, but governments and individuals must learn from this pandemic on how to reduce pollution in the long run ( Muhammad , 2020).

However, the negative impact of the pandemic is still going on. The amount of poor people in Indonesia as of March 2020 was 26.42 million or $9.78 \%$. This figure increased from the previous year, which amounted to $9.41 \%$ or 25.14 million inhabitants. The most significant percentage of the sparse population found in Maluku and Papua, which is $20.34 \%$. At the same time, the lowest rate observed in Kalimantan at $5.81 \%$. Indonesia's Poor Population Increases 1.63 million People amid pandemic Covid19 (Central Bureau of Statistics, 2020). The 2015 Intercensal Population Survey (SUPAS) estimates that Indonesia's population in 2020 will be 269.6 million from 32 provinces and 2 distinctive regions. The number of male people is 1.07 million more than women. While based on the age group, the number of productive age population (15-65 years) reached $68.7 \%$ of the total population. While the non-productive age group (0-14 years) is $24.5 \%$, and the non-productive age group (over 65 years) is $6.7 \%$ of the total population. Indonesia is in an era of demographic bonuses where the number of productive age population is higher than the number of unproductive people. Indonesia's economy grew 2.97 per cent year-on-year (YoY), slowing down considerably from 5.07 per cent in the first quarter. Then it affected the employment sector because more than 1.5 million workers were laid off (90\%) and laid off (10\%). For the record, the number of active workers until 11 April 2020 was 1.24 million formal sector 
workers and 265 thousand workers from the informal sector (Central Bureau of Statistics, 2020).

President Joko Widodo responds the pandemic Covid19 by allocated more than 152 trillion IDR in various program to cover poor people, and the households to allow unemployed worker, taxi driver and buses. The main point is to raise the Indonesian economy as well as to save Indonesian from Covid19 (SETKAB.GO.ID. , 2020).

\section{Suggestion Indonesian Food Security Programs in Pandemic Era}

Although the amount of food production is currently undergoing no change and can still be said to be safe, the problem of the food crisis can even occur in the future. The biggest problem occurs in food distribution. With restrictions, food distribution is weak. As a result, food stocks rarely distributed in all regions. Moreover, climate change will be a permanent issue with drought and its impact on agriculture and food production. Based on those alarms, what we need to remind and start focusing on;

\section{Conservation}

Indonesia has a vast biodiversity to support food security. However, how to manage natural resources become local food resources is something fundamental, mainly for economic and food security. Therefore, conservation is necessary to sustain the environment. The existence of local food also depends on the sociocultural context in that region. Thus, the local Government should have enough knowledge to identify local food and implement conservation into the regulation.

\section{Seed Banks}

Each region has specific and unique biodiversity. Even though the same family in crops, but they have different benefit and taste. Local Government need to care and raise this biodiversity as a superior landrace, which is an excellent variety in the future. Seed banks are also another strategy to develop sustainable agriculture.

\section{Water Reservoir}

Regarding harvest, the crops all the season, the water reservoir is a must. People can save the rainfall into an artificial lake and use it in the drought season. Another way is to build wells in some points.

\section{Optimization of pendant land}

To meet balanced nutrition for a family, we need to plant many kinds of crops, such as alternative food crops. These crops can be resources of carbohydrate \& protein. In the same time, people also plant vegetables, fruit, as well as protein sources (fish, chicken, duck, etc.). They hold together those crops and animals in the same area for food security in family level.

\section{Urban Farming}

When the employees work in the city, and they left their village, they need to secure their food with planting in the small area, such as hydroponic, verticulture, aquaponics, etc. Therefore, agricultural technologies are flexible and possible in any field. The main thing is own desire to full fill the need of food by planting and greening their areas.

\section{Penta helix}

Ensuring food security in the pandemic era in Indonesia, the Penta helix has to implement to speed food security. In the Penta helix, Government, private sector, research centre, community, and social entrepreneurs have to work altogether. Government has to prepare varieties of crop strategies, also doing such as monitoring the stability of prices and increase national 
agricultural production based on smallholder agriculture and in favor of small farmers. The Private sectors can act as a supplier as well as the loan provider. The research centre of the institution could develop new varieties and advanced technologies, views, thoughts and input on policy strategies. Those things can hold by the Government and create innovations that can guarantee food availability in the new standard era of the pandemic COVID 19. Community or civil society can be a producer of food and goods. The agricultural sector is strategic and must get attention because it has a large workforce, where production has decreased, but consumption is high. The challenge meets the food needs of the community to ensure food security and on the other hand, also contribute to economic recovery as well as to sustain the environment.

Let's start from ourselves, starting from small things, maintaining a clean and healthy lifestyle and being able to use vacant land to become productive and environmentally friendly area.

\section{REFERENCES}

Muhammad, S. (2020). Science of the Total Environment.

Braun, J. (2008.). Food and financial crises: Implications for agriculture and the poor. Washington, DC, International Food Policy Research Institute (IFPRI); IFAD. 2016. Rural Development Report 2016. Fostering inclusive rural transformation.

Central Bureau of Statistics. (2020). Economic Indicators April 2020. BPS - Statistics Indonesia. ISSN.0126-2319
Publication

Number:

07330.2007. 234p.

FAO, IFAD, UNICEF, WFP and WHO. (2019). The State of Food Security and Nutrition in the World 2019. Safeguarding against economic slowdowns and downturns. Rome, FAO. Retrieved from http://www.fao.org/3/ca5162en/ ca5162en.pdf retrieved 17 June 2020.

FIVIMS. (2002). Food Insecurity and Vulnerability Information and Mapping Systems The FIVIMS Initiative: Food Insecurity and Vulnerability Information and Mapping Systems: Tools and Tips; IAWG-FIVIMS Secretariat: Rome, Italy, ; $\mathrm{p}$.

Food and Agriculture Organization of the United Na. (2003). Trade Reforms and Food Security: Conceptualizing the Linkages. Food and Agriculture Organization of the United Nations, 313.

Galanakis., C. (2020). The Food Systems in the Era of the Coronavirus (COVID-19) Pandemic Crisis Foods. www.mdpi.com/journal/foods . doi:doi:10.3390/foods9040523

Pérez-Escamilla, R. (2017). Food Security and the 2015-2030 Sustainable Development Goals: From Human to Planetary Health. Current Development in Nutrition 1, e000513.

Pingali, P., Alinovi, L. \& Sutton,J. (2005). Food Security in complex emergencies: enhancing food system resilience. Disasters. 
SETKAB.GO.ID. . (2020). Press Statement of President of the Republic of Indonesia on Government Policy to Handle the Impacts of COVID-19 Pandemic. Retrieved from https://setkab.go.id/en/pressstatement-of-president-of-therepublic-of-indonesia-ongovernment-policy-to-handlethe-impacts-of-covid-19pandemic-thursday-9-april2020-at-the-merdeka-palacejakarta/

United Nation. (2015). Transforming Our World. The 2030 Agenda for Sustainable Development. Retrieved from https://sustainabledevelopment. un.org/content/documents/2125 $2030 \% 20$ Agenda $\% 20$ for $\% 20 \mathrm{Su}$ stainable $\% 20$ Development $\% 20$ web.pdf

WRI.Indonesia.org. (2019). WRI Indonesia Director Indonesia's Development: $\quad$ Challenges, Risks, and The Way Forward. Retrieved from https://wriindonesia.org/en/about/message -wri-indonesia-director 